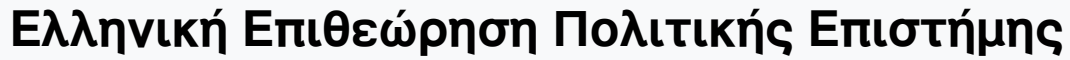

Tó 39 (2012)

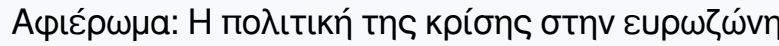

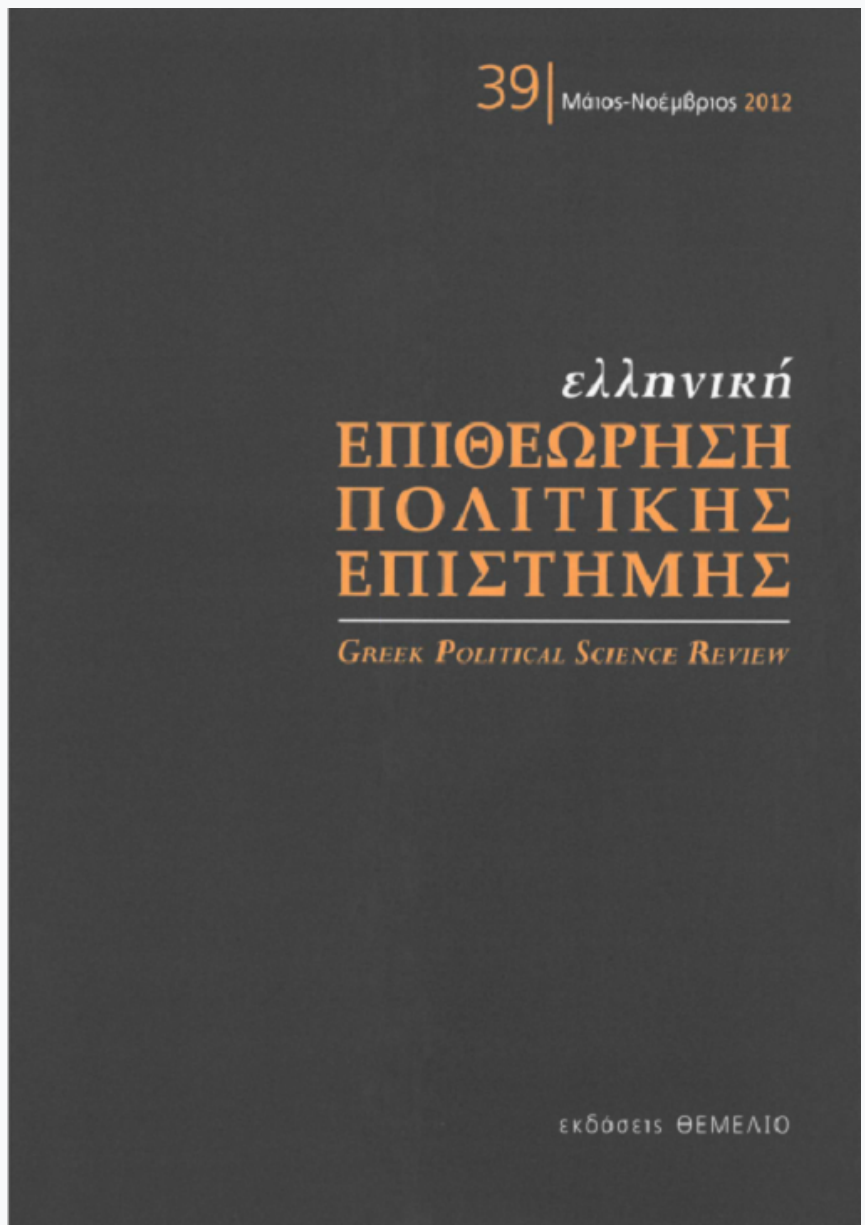

\section{Humiliation and Greek debt}

Dennis Smith

doi: $10.12681 /$ hpsa.14549

Copyright $@$ 2017, Dennis Smith

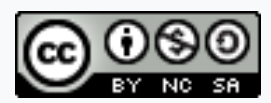

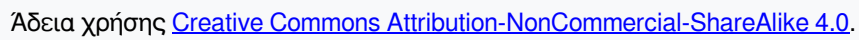

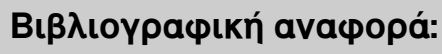

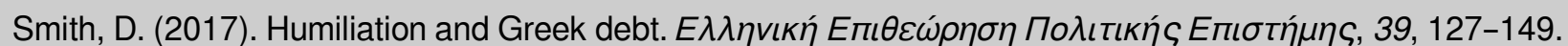
https://doi.org/10.12681/hpsa.14549 


\title{
Humiliation AND GREEK DEBT
}

\author{
Dennis Smith*
}

This article, the basis of a talk to the Hellenic Political Science Association in March 2012, presents an approach to the analysis of humiliation or forced social displacement. It makes reference to the particular example of Greece during the sovereign debt crisis and offers a comparison with the effects of Hurricane Katrina on New Orleans. Distinctions are made between yielding responses and challenging responses to humiliation, including escape and acceptance in the first category, and resistance-rejection, revenge-rejection and conciliation-reform in the latter category.

\section{I}

I am delighted to be in Athens talking to colleagues in the Hellenic Political Science Association. ${ }^{1}$ I am bringing with me some ideas I have been developing over the past few years about the dynamics of humiliation, or forced social displacement, and especially responses to the threat or experience of humiliation. As this is my first visit to Greece I do not, so far at least, have any direct experience of the "feel" and texture of everyday Greek politics and social life. In spite of this, I am being bold, or foolish, enough to talk to an audience that is thoroughly expert about the harsh and challenging situation that this article explores: not just experts in theory but also thoroughly involved in it every day. For me, coming to Athens to do this talk is a little like flying into Kathmandu to give a talk on Mount Everest to a gathering of Nepalese mountain guides. ${ }^{2}$

* Dennis Smith is Emeritus Professor of Sociology at Loughborough University, UK.

1. This text provided the basis for my presentation in Athens on 7th March 2012. I am very grateful for the invitation to address the Association, and for the opportunity to talk informally about the issues with colleagues in Greece during my visit. I owe special thanks to Nicolas Demertzis, Michaels Spourdalakis, Costas Eleftheriou, Vasilis Rongas and Kanakis Leledakis.

2. Looking back on my visit to Athens, five factors that I now think I underplayed in this 
As everybody knows, the present time, early March 2012, is one of great uncertainty. The latest Greek loan has been agreed but nobody knows what will happen after the next parliamentary elections currently scheduled for April 2012. In spite of this uncertainty, it is worth trying to get a theoretical understanding of the dynamics of humiliation because this may provide some insights into the current situation as Greeks face up to demands for ever-increasing austerity and self-sacrifice.

I begin by noticing two things. One is that the current Greek crisis is a complex mixture shaped by factors such as: the geo-political constraints relating to Greece's location in South-Eastern Europe; the deep involvement of foreign governments in Greece's internal affairs; the strong hold of clientelism and patronage; hard bargaining over international loans and the handling of debt; and deep feelings of humiliation and resentment. The second thing I notice is that Greece has been in similar situations before in the course of its history where these factors have been present. For example, the Greek revolt against Ottoman rule in the 1820 s was accompanied by an effective campaign by expatriates, migrants and foreign sympathizers in Europe and the American Republic who all emphasized the humiliation being undergone by the Greeks. Paintings by Delacroix, depicting Greeks as suffering victims, were one part of this. One outcome of this campaign was that loans were raised from the British government, and later from Britain (again) and, France and Russia.

Now, these loans were not given out of pity for the Greeks, although obviously those feelings were very strong in many quarters. Foreign governments were willing to make these investments because of Greece's geo-political situa-

article are: the latent feeling among PASOK veterans that they were entitled to the rewards and good times they enjoyed in the 1980s and after as compensation for their suffering and exclusion in earlier decades; the embarrassment and even shame felt by many small private sector businesses at the publicity being given to their history of non-payment of taxes; the halfopen, half-hidden role of powerful business interests, which are not necessarily entirely sympathetic in practice to the implementation of medium- and long-term strategies for strengthening the Greek political economy in the interests of the majority of citizens; the dense presence of Greek broadcast and print media which provide a very thick cloud cover over the political and economic landscape, able to skew and obfuscate debate, being by turns vitriolic and entertaining; and, not least the overwhelming national dominance of Athens, an urban zone containing a third of the Greek population, served by over twenty national newspapers, roughly the same number as the United Kingdom whose national population is over five times greater than that of Greece. 
tion, being close to vital Mediterranean sea lanes and a good place to keep a close eye on the slowly crumbling Ottoman empire. There was, however, a political price to pay for those loans. Many leaders of the Greek uprising wanted a constitutional government without a monarch but they were forced to accept a German prince with a taste for absolutism as their ruler. The price of foreign loans was foreign interference.

There is no need to present a long litany of historical evidence but it is worth recalling the work of the so-called International Financial Control that intervened directly in Greek government finances after Greece's disastrous war against Turkey in 1897. A few years earlier, the Greek government had declared itself bankrupt in 1893 and secured large loans in London, Paris, Berlin and Constantinople. These loans presumably helped pay for the war. The International Financial Control, run by Europe's big powers, set itself up in Athens in 1898. It took complete charge of collecting the sales taxes due on various government monopolies. The idea was to make sure the Greeks made repayments on foreign loans going as far back as 1833. The International Foreign Control continued in existence until 1965.

With that background in mind, let us turn to Syntagma Square in the centre of Athens in 2010 and 2011. Over the past few months Syntagma Square has been like a gigantic megaphone or loudspeaker. It has blared out a distress call, a prolonged and insistent distress call, fuelled by anger, fear and grievous suffering. How could it be otherwise when youth unemployment rises to nearly fifty percent, when wages in the public sector are cut by over eighteen percent one year, and then again by eighteen percent in the following year, with more to come? Or when the minimum wage is to be cut by twenty-two percent? Or when taxes on ordinary citizens are increased while public expenditure on social services is radically reduced? Or when a large number of solid citizens with nice houses in the suburbs holding good middle level jobs in management and the professions suddenly find they are out of work and cannot pay their mortgages?

The main message being conveyed by men and women in the streets of Athens is intense indignation and outrage. It is clear that citizens feel they are being penalized for crimes they did not commit. Meanwhile, it seems to them that the perpetrators, the guilty ones, are escaping punishment and they are not changing their ways. Outside Greece, in Europe at large, as far as I can tell the dominant opinion in the streets is that the blame lies, quite simply, with "the Greeks." This verdict does not make any distinction between politi- 
cians and Greek citizens, which is, of course, unfair. The implication, however, is that "the Greeks" should, so to speak, "sort themselves out" and "put their affairs in order."

By contrast, within Greece itself there seem to be many candidates for the title of "guilty ones" including international bankers, EU politicians and officials, Greek politicians, and "the Germans" with whom, of course, Greeks have had a rather unhappy relationship in the past, especially during World War II when Greece was under Nazi occupation between 1941 and 1944.

On February 9th 2012 the populist newspaper Dimokratia printing on its front page a depiction of Angela Merkel in a Nazi uniform next to the headline "Memorandum Macht Frei". This puts together in one phrase Auschwitz and the Greek government's memorandum to the IMF on May 2010. This memorandum promised to achieve "higher and more equitable tax collections", and to "constrain... spending in the government wage bill and entitlement outlays". By contrast, the next day, February 10th, we have the Luxembourg Prime Minister Jean-Claude Juncker declaring: "No disbursement without implementation". This brings together in one phrase the IMF memorandum and the American War of Independence. Then on February 11 th we had George Karatzaferis, the extreme right-wing leader of LAOS, (the Popular Orthodox Rally) resigning from the Papademos coalition government along with several other colleagues. Karatzaferis reportedly said: "What has particularly bothered me is the humiliation of the country". He added that he could do without "the German boot". ${ }^{3}$

This present article does not and could not try to unravel the Greek crisis or predict its eventual outcome. However, it will hopefully help us make sense of the crisis if we try to understand more about the nature, causes and consequence of humiliation, a process that has a variety of expressions and many $\mathrm{d}$ ifferent effects. That is what the next part of the article is about. Then in the final part of the article I will briefly explore some implications of the general analysis for the particular case of Greece and the EU.

3. As reported in The Guardian, 10 February 2012. We can add to this volatile mixture factors such as the frequent anti-German comments of television presenter Georgios Trangas, the cartoons of Stathis Stavropoulos, depicting contemporary German leaders in military uniforms from the 1940s, and the burning of a German flag by demonstrators. 


\section{II}

I am mainly going to be talking about how people respond when they have suffered humiliation but first I will say something briefly about humiliation from the point of those who deliberately impose it on others. ${ }^{4}$ For people who impose humiliation on others, one reward is the pleasure of demonstrating their strength. That includes both the capacity to prevent other people from harming you and the capacity to damage or destroy other people if you choose to do so. Humiliation is at the very heart of the very ancient (but still very much alive) honour code, which says that the only thing that truly commands and deserves respect is strength: both creative and destructive. I should add immediately that imposing humiliation on others may also lead to, or be accompanied by, various other rewards for the perpetrators such as a reduction of the victims' resistance to their own plans for socio-political change.

Humiliation, has three "moments", to borrow, and adapt, a Hegelian term. These moments may appear separately, in sequence, or all together. In Syntagma Square they have appeared all together, seen from the perspective of the victims. First, there is the moment or phase of defeat and subjection to conquest. This happens when people that have tasted liberty, the capacity for autonomous action in pursuit of their own freely chosen goals, discover that their hands are tied. They have overwhelmed and put under restraint: they have been fitted with a straitjacket and had their wrists clamped inside handcuffs.

For example, as is well known, Brussels virtually imposed a new government on Greece led by Lucas Papademos, a former Governor of the Bank of Greece. Also, the German government proposed that an EU budget commissioner should be appointed to take control of Greece's tax and spending, presumably to make sure that Greece behaves "properly" in return for being given further loans to deal with its large public debt.

Then comes the moment of relegation or being pushed down the order of power and status. The promise of Europe -the "European Dream" so to speak- is that when a people join the European Union they are entering a promised land of equality amongst European nations. Joining the EU is anticipated as a process of emancipation and enhanced national status and recognition. But in the past few years, for Greece this has turned out to be a monstrous fantasy, a chimera. It seems that when the chips are down, or when the

4. I should say that not all humiliation is deliberate. Sometimes it can happen by accident. 
chips run out, control lies with the North of Europe: Brussels, Berlin and Paris. At that point it turns out that certain Southern members of the EU, such as Greece and Portugal, are near the bottom of the European political league table.

The third moment is exclusion. People have arrived at this point when they notice that even when they (Greece) are the main topic of debate they (the Greeks) cannot be heard within that debate. No one is listening to ordinary Greek people, it seems. Their own plans and proposals are ignored and their own hopes for the future are discounted and written off. This sense of exclusion is intensified when the "normal" transmission belts for exercising influence in a capitalist democracy turn out to be much less effective than before. The power to spend or not to spend is weakened when the people's spending power is gone. The power to vote for this or that party is a puny one when most people distrust almost all those politicians. The power of strike action is reduced when a substantial part of the trade union leadership seems to be committed to imposing austerity rather than modifying it substantially. And the power to demonstrate peacefully is ineffective when the government has made itself deaf to the noise outside.

To summarize, humiliation as conquest, relegation and exclusion adds up to a forcibly imposed loss or radical reduction in freedom, recognition, agency and security. To put it another way, it is a forced social displacement that is experienced as degrading.

People "feel humiliated" when they are pushed about, pushed down, or pushed out in an offensive way, not necessarily physically, but psychologically and socially. At the heart of humiliation, for those at the receiving end, is the experience of involuntary displacement from their established and familiar social position and social identity.

These feelings are experienced by individuals but often in a collective context, for example in a crowd, or as part of the crew in a battleship, or as the member of a government ministry, or as a work-force. The responses of those who have been humiliated may also be collective, like a riot or a strike, and may have large effects such as the breakdown of socio-political order, the outbreak of war, or revolutionary uprisings.

Being humiliated produces intense discomfort in the person or group at the receiving end. It means being forced to acquiesce in something that seems totally unacceptable by those subjected to it. The immediate source of discomfort is the unpleasant difference between two things: on the one hand, 
the sufferers' own sense of who they are and where they fit into the world; and, on the other hand, the demeaning identity and unworthy social position that the act of humiliation imposes upon them.

The discomfort is compounded by realisation that the forced social displacement has brought about an unwelcome reframing not only of the sufferers' location in social space but also their location in social time. In other words, their perception of their own past, present and future is transformed. The past seems brighter than before, the future worse than they previously expected, the present less bearable than it used to be.

Humiliation is dislocating, and dislocation always causes intense discomfort, whether it is dislocation of a shoulder or dislocation of a social identity and a planned career. Humiliation therefore requires action to relieve that discomfort. Reflection is one form of action, and may indeed be the only one available in certain circumstances, for example during a prison sentence. ${ }^{5}$ However, other forms of action may also be possible. These are typically directed at bringing about transformations by, for example, strengthening the threatened self, strengthening the threatened group, reducing the extent to which the self or the group are in vulnerable situations, reducing the extent to which the humiliating agent is able to be effective, or reducing the extent to which the socio-political structure creates humiliating situations.

These possibilities may be simplified into the statement that there are three directions in which action may be possible: towards the "inner", the "outer" and the "other" (see appendix A, figure 1).

By action towards the inner, I mean action intended to preserve or (more likely) reshape the inner constitution and dynamics of the person or group, including their assumptions, habits and capacities. By action towards the outer, I mean action intended to preserve or (more likely) reshape the social and/or political structure and/or pattern of external relations in which the person or group is embedded. By action towards the other, I mean action intended to preserve or (more likely) reshape relations with the threatening rival, enemy or oppressor that is the direct agent of humiliation. I shall try to illustrate these forms of action in the case of specific types of response to the threat or fact of humiliation.

I want to divide the potential reactions of those who experience humilia-

5. I have written a paper on the prison experiences of radical writers and political leaders, which will be appearing in a book entitled Emotions in Politics edited by Nicolas Demertzis to be published by Macmillan. 
tion into two kinds of movement: backward away from the threat, and forward to meet the threat; in other words, yielding responses and challenging responses (see appendix A, figure 2). I am going to begin by discussing two yielding responses: acceptance and escape.

Acceptance of humiliation is more than mere passive acquiescence. Acceptance means redefining the forced social displacement as appropriate and deserved. This means signalling agreement with the norms, values and judgements expressed in the humiliating action that has hurt them. Once those at the receiving end agree that they have been justly punished for their own faults, the way is open for their initial feelings of anger and fear to be replaced by feelings of shame caused by awareness of their own wrongful actions or attitudes in the recent past.

Newly awakened, so to speak, the accepters come round to agreeing with their "oppressors" that the new social position and social identity assigned to them against their will are, in fact, appropriate. They realise that they should, in fact, bow down before the judgement that has relocated them in this way. Perhaps a good example of this would be the conversion of governments that initially opposed the so-called Washington Consensus, with its emphasis on privatization and business-friendly tax regimes, following "persuasive" visits by representatives of the World Bank or International Monetary Fund.

However, acceptance may be outward only, and hedged about with internal reservations. If so, it may, or may not, become more "genuine" with time. In any case, the success of an acceptance strategy depends on two things (see appendix A, figure 3). One is the level of trust that can be built and sustained between the parties concerned. The other condition is whether the more powerful partner, the one responsible for the initial process of humiliation, can exhibit sufficient reciprocity to persuade the repentant victim that they can be re-integrated into the relationship in a way that is satisfying for all. But these two things may fail to occur. This seems very relevant to the current Greek situation since one of the things that make the current situation seem so unfair from the Greek citizens' point of view is that the austerity being demanded of them does not seem to be matched by practical help of some kind from the EU to enable Greece rebuild its economy and strengthen its political institutions.

The danger for the willing victim is that those who control their fate may regard them as intrinsically unworthy, irrespective of how they are behaving. If this is the case, they may become vulnerable to a cycle of victimization in- 
volving further acts of humiliation. It seems clear that repeated victimization is the fear, indeed the experience, of those who protest in Syntagma Square. It can be suggested that prolonged victimization sometimes lead to a revenge response by the victims, all the more effective for being unexpected.

Accepters reform themselves without relocating themselves. They stay and face the music. They re-make themselves in the image required by those who have power over them. By contrast, escapees -to whom we now turn- relocate themselves without reforming themselves. They go away so they can make their own music elsewhere. They re-make their new society, home or "promised land" in their own image.

In contrast with acceptance, which seeks to remove the victim's objection to the humiliation itself, escape is a strategy of physically moving the intended object of humiliation away from potential harm. The object of escape is to find a well-defended place where the escapees can "be themselves", untroubled by "others". A classic case is America's "Pilgrim Fathers" who sailed from Plymouth in the early seventeenth century to "the new world" in order to escape religious persecution. Unlike accepters, escapees do not give up the project of building a better society or a better home in which they can live more happily without humiliation. However, they decide to pursue the project somewhere else, far away, where nobody can stop them. They endeavour to make a society that conforms to how they are: for example, in the new American Republic, or South Africa, or Israel, for example.

Escapees, and the descendants of escapees, in America and elsewhere, are likely to feel wounded and distrustful, inclined to expect the worst from their neighbours. A key factor is whether or not escapees can restrain their fear of others; a difficult proposition especially since "others" that are unknown and different almost always do, in fact, exist. If such "others" are held to be a potential threat the dangerous possibility exists that this attitude may lead to repeated "pre-emptive strikes" against any unfamiliar strangers who stray into their vicinity; in other words, it may lead to a fear cycle. These aggressive actions are likely to cause deep resentment among the victims thus creating the very enemies that were feared. These new enemies may seek reprisals. In this way, fear cycles, the repeated striking out against real or imagined dangers, may be rapidly converted into a series of revenge cycles as hurt victims strike back in anger.

There is a final set of differences between escapees and accepters: when faced with "others" that are potentially threatening, the accepters try hard to 
bring about a positive engagement with them but the escapees are much less inclined to do this. This means that accepters, unlike escapees, acquire valuable experience of a kind that may empower them in a wide range of future situations. The point is that their attempts to engage in positive engagement with the oppressive or aggressive "other" give accepters practical knowledge about where the other's strengths and weaknesses are, and about what works or does not work in dealing with them.

Furthermore, if accepters are acting out a part, presenting the "required" face to the "master", they develop their skills of deception. In effect, they learn to cultivate both an inner self and an outer self and use one to control the other. These skills can all be useful in a wide range of situations. Finally, accepters develop the capacity to self-transform. They learn how to work on their own individual self or the group's sense of identity so as to mould it to the needs of the situation. The point is that those who have remade themselves by becoming accepters know the relevant techniques and in many cases can do it again, changing themselves in another direction, if and when it becomes necessary.

Turning to challenging response to humiliation, we can distinguish between rejection, which directs its attention to the effects of humiliation, and another approach, here labelled conciliation-reform, which works to decommission the causes of humiliation by combining conciliation through truce and dialogue with reforming initiatives in relation to the "inner", the "outer" and the "other".

Rejection, like acceptance, requires the ability to self-transform, to work upon the "inner". For example, it is significant that the clearest message conveyed by Nelson Mandela to his followers in the Black townships when he was finally released from jail was: educate yourselves, go back to school. Individual and collective self-strengthening were vital. That was Mandela's preferred route for raising the condition of Black South Africans.

Education would ensure that Black South Africans could take their proper place as fully emancipated members of post-apartheid society. That meant restraining the anger that led to reprisal attacks on Black policemen. These were people who had been enforcing law and order on behalf of the apartheid regime and were therefore enemies, as their attackers saw it. This issue exposes a fundamental division between two strategies within the rejection approach. We can label these resistance-rejection and revenge-rejection.

Resistance-rejection seeks to do three related things: to undermine the op- 
pressor or enemy; to protect the individual or group under threat; and to build up the capacity and resources of the threatened individual or group, not only for defence but also -and this is very important- for development in a direction that allows them to fulfil themselves.

In the case of Mandela and his co-workers, that meant teaching the rank and file of the African National Congress (ANC) how to be restrained and how to build up their own skills and reliability. It meant training the leadership of the ANC how to rule, how to have the confidence and strategic intelligence they would need when they eventually got into government. It also meant undermining the humiliating agent by protecting the targets of abuse from degradation and building up their strength. That was the ambition that lay behind the carefully calculated campaign of insurgency carried out by the African National Congress (ANC). The object was to undermine apartheid, but definitely not to massacre Whites or kill Black Africans who were part of the regime's bureaucracy.

Nelson Mandela, for one, realised that at some point there would have to be positive (ie peaceful) engagement with the apartheid regime itself, speaking to those who had traditionally opposed socio-political change. When that happened, the ANC would be able to build on the ground won through their strategy of resistance-rejection. As things turned out, in the end the White minority regime was eventually prepared to negotiate change. That made possible a shift by the ANC away from a sole reliance on the resistance-rejection strategy, which was fundamentally negative, expressing a determined refusal to acquiesce in oppression. The ANC moved to a twin-track approach, which ran the resistance-rejection strategy alongside a strategy of conciliation-reform, leading in this case to the abolition of apartheid.

However, as we have seen, there is another rejection strategy and that is revenge-rejection, the approach followed by those who seek the satisfaction of revenge, perhaps because no other approach seems possible. So, what does revenge involve? It means the recovery of honour and self-regard by striking back against a target closely associated with a hated oppressor or enemy, causing as much damage as possible.

The revenge-rejection strategy bypasses and pushes aside any consideration of structural reforms aimed at removing the causes of socio-political degradation. It does not take that route. Instead it seeks to inflict damage and impose a counter-humiliation. It strikes out at any vulnerable aspect or symbol of the hated enemy upon whom revenge is being enacted. A successful revenge at- 
tack gives an immediate boost to those who are disheartened or disgusted by being humiliated. This is because it turns the tables, for a while at least, on whoever or whatever is causing their own humiliation.

However, revenge may also have disadvantageous effects for those who inflict it. If you burn down your local budget-price supermarket, where do you shop next week? If you take part in a prison riot, where do you get breakfast while it is going on? Even more important, revenge does not normally come in single acts followed by a full stop. Instead, it almost always invites, even demands, an answer on the part of the recipient. It is part of a nasty and often violent "conversation" that may be difficult to end except through mutual exhaustion or the utter defeat of one side or the other.

Despite these disadvantages, revenge cycles occupy a key position in the "machinery" of humiliation, as we have seen. When anger dominates rejection responses, the outcome is often a strategy of revenge-rejection leading to revenge cycles. When the escape response fails to master and minimise fear, this leads to distrust of strangers and of independent-minded neighbours, resulting sometimes in fear cycles, which may, once again, trigger revenge cycles. When the acceptance response does not engender trust and reciprocity, repeated victimization may occur leading to distrust, then anger, then a resort to revenge. As we will see, even the conciliation-reform approach is vulnerable to the onset of distrust and the resurgence of revenge-cycles

In fact, revenge and revenge cycles are like a huge conduit or channel receiving from above all the gravity feeds just mentioned. Revenge welcomes into its huge mouth all those who initially pursue escape, acceptance and resistance-rejection strategies, but encounter failure, and find themselves striking back at old or new enemies. Revenge is the default mode of responding to humiliation, when all else has failed. For anyone who cares about human rights this is a very unfortunate situation.

The situation is unfortunate because revenge is a concept drawn from the heart of the honour code (see appendix A, figure 4). This code is a way of judging behaviour that greatly values the very ability to impose humiliation on others. The capacity to strike down those who displease you has been for centuries accepted as something glorious. It is central to the existence of the feudal lord, the traditional aristocrat, the warring tribe, some football fans, some newspaper editors, some politicians and, indeed, the state, both yesterday and today, especially its military wing, and especially at times of confrontation with its external enemies. Some aspects of the honour code can also be dis- 
cerned, perhaps, in the neo-liberal approach to the market, which relishes economic struggle, glorifies "winners" and shows contempt for "losers".

Adherents of the honour code bow down low before those who have sufficient resources and organisational capacity to strike down and destroy others or to nurture and protect them, depending on which they choose to do. That is obviously the opposite stance to the one taken by the human rights code, which "outlaws" humiliation to the best of its ability. The human rights code is a relative newcomer to human history. There were, of course, very important glimmers of it in ancient Greece and the religions of Abraham. However, these ideas acquired enormous world-wide prestige following the success of the independence struggle in the American Republic and the abolition of the French monarchy and aristocracy during the French Revolution.

In sharp contrast to the honour code, the human rights code respects the principle that all human beings have a legitimate expectation to be treated humanely. In other words, they should not be penalised or disadvantaged on the grounds of gender, ethnicity, religion, sexuality, or because they are physically or mentally challenged in some way. Furthermore, all human beings have a right to the means of living a healthy, secure and fulfilling life.

As is well know, Alexis de Tocqueville predicted in Democracy in America that the honour code, the code of Tocqueville's own social class, the aristocracy, would disappear with the rise of democracy and the human rights code. In fact, today the two codes coexist in all modern societies. Meanwhile, the built-in drift towards revenge-rejection when other strategies fail favours the honour code. This makes it possible that the changes in law and behaviour made in support of the human rights code over the past two centuries might be reversed.

To put it another way, if fear and anger repeatedly get out of control, if trust and reciprocity fall into decay or are not carefully cultivated and rebuilt, then all responses to humiliation will lead in the end towards the politics of resentment and revenge and the squeeze on human rights will intensify. The honour code will rule. Strength and weakness will be the only language.

If this analysis is correct, the drift towards revenge-rejection as a response to humiliation has been repeatedly occurring for centuries, maybe millennia. So what is new? The point is that the human rights that have been secured by trade unions, campaigning professional groups, and movements for democracy over the past two centuries have been "stored" or "banked" in national citizenship rights and national legal systems. That is, of course, how they get in- 
stitutional embodiment and become available for future use. So those that value human rights have a substantial asset banked in various national states.

However, during and since the 1990s and 2000s, more aspects of our lives are controlled and influenced by market and cultural forces that are beyond the control of national states. This means that national states are becoming relatively weaker and less able to enforce their will, and this weakens the institutional defences of the human rights code. While humiliation cycles persist, the secular drift towards revenge is likely to shift the balance of advantage away from human rights towards the honour code, perhaps decisively.

Seen from this perspective, added importance is acquired by the strategy of conciliation-reform, which seeks not just to undermine the effects of humiliation but also to remove the structural sources of humiliation. Observation suggests that conciliation-reform is most likely to be attempted after a revenge cycle has been underway for some time between two states, groups or individuals and each is accusing the other of aggressive behaviour that inflicts unjustified and despicable humiliations upon them.

If the costs of conflict escalate and become debilitating and exhausting, a cessation of violence may sometimes become possible. This may give the opportunity for conciliation to take place. In other words, the people involved look for a way to manage their differences peacefully and through dialogue, and try to build a stable relationship in which they can each achieve their goals and can also achieve some shared goals. Where conciliation is attempted, the idea is that dialogue may lead towards increasing trust, the gradual emancipation of all parties from the old hatreds, and reform of the humiliating structures and processes.

But truce talks may be hindered by resurgences of distrust. The truce may be simply used as a way for opposed and contesting parties to get their breath back before they move back into more open and less restrained struggle. If that pattern prevails then the result is a distrust cycle: exhaustion, truce, dialogue, distrust, return to conflict and the revenge cycle, more exhaustion, another truce, another attempt at dialogue, renewed distrust, and eventually a withdrawal from conciliation. The default position is, once again, the revenge cycle.

For an emancipation process to succeed, the parties involved in the attempts at conciliation need to be prepared to engage constructively with each other, be ready to undergo self-transformation, and be committed to undertaking reform of the structures and processes in which they are mutually involved.

At this point it would be worth having another look at the analysis we did 
earlier. I argued that the experience of humiliation was likely to strengthen the disposition of some individuals and groups to try and transform three aspects of their situation: the "inner" self, the "outer" socio-political context in which they were embedded, and their relations with the "other": the enemy, rival or oppressor responsible for their humiliation. Perhaps at this point we can draw some preliminary conclusions about how the different kinds of response to humiliation are likely to shape the dispositions in these three respects of the people involved (see appendix A, figure 5).

Escapees and revenge-resisters are the most "conservative". They need to have courage to take the risks of encountering the unknown. They also have to toughen themselves up to withstand the rigours of travel and battle. However, those factors do not, in themselves, make them flexible and openminded. Escapees are in search of somewhere that "suits them better". This means they have only a very weak disposition to change themselves or the "old" social environment that is the source of their initial humiliation; and they have no interest in dealing further with their old oppressors. So they score low on all three counts, relating to the inner, the outer and the other. The same is true of revenge-resisters who are above all keen to "score for their team", not to undertake positive engagement with the other or undertake major structural reform.

Compare those who seek conciliation-reform. They have positive orientations towards transforming the inner, the outer, and relations with the other. In many circumstances, conciliation-reformers will be in a minority but this analysis suggests they may find allies. For example, resistance-rejecters have strong dispositions towards self-transformation and structural reform. For their part, acceptors are experienced in self-transformation and positive engagement with the other. This suggests that those who seek conciliation and reform through truce and dialogue may find allies amongst disillusioned accepters, and resilient resistance-rejecters. Such an alliance may have the best chance if revenge-resisters are exhausted, especially if some of them have strong sympathies with resistance-rejecters.

\section{III}

Finally, let us return to our starting point, the current crisis with particular reference to Greece. The level of public debt in Greece became an issue when 
the credit crunch, which had originated across the Atlantic, struck Europe. In some key respects, the impact of the credit crunch was rather like the arrival of Hurricane Katrina on the southern seaboard of the United States. Katrina tested the fortifications that had been built against the raging sea. In New Orleans, which was largely built below sea level, the levee failed and the floodwaters rushed in, devastating the city.

There followed a huge row about whose fault it was that the fortifications had not been built more strongly, with both the local administration and the federal government trying to avoid the blame. To summarise a complex situation in a few words, Washington was very slow in coming to the rescue of the citizens of New Orleans and the people in that city felt that they were being regarded "from above" as useless, not worth taking any trouble over.

The city of New Orleans is, of course, a very different case from the nation of Greece in several important ways. However, the comment on abandonment signals a point of contact between the two cases. Underlying the anger and distress in Athens there is, surely, the very deep shock of discovering that that the leaders of the $\mathrm{EU}$ are abandoning the Greeks to their fate.

The shock stems from the fact that Greeks entered the EU in 1981 with great enthusiasm having struggled out of the grip of military dictatorship only a few years before. In a thoroughly positive and proud spirit they embraced its democratic ideals and its commitment to the human rights code. When the credit crunch arrived, this commitment failed at crucial points. As in New Orleans, there is some feeling in Greece, rightly or wrongly, that the treatment of the Greeks goes beyond mere neglect and involves deliberate brutalisation and victimization. In Athens, at least, this is partially counter-balanced by an acceptance response, justifiable or not, that perceives the situation the Greeks find themselves as being "our own fault", the result of unwise actions by both politicians and private citizens. This "acceptance" response is, of course, quite compatible with a feeling of being victimized, a feeling that stems from a lack of trust and reciprocity on both sides.

The main result of this lack of trust and reciprocity has been that the EU has not had the political will to exercise one aspect of the human rights code, which is the duty of care towards all citizens. This is the idea that the relevant community through its governmental agencies accepts responsibility to see that standards of civilized living are maintained for all citizens, who have a right to recognition, security, freedom and agency.

This is relevant because there have been two huge "selling points" that 
made the European Union attractive to ordinary citizens over recent decades. One has been that, to a greater extent than the United States, the EU has strongly promoted legislation and public funding to support social rights such as a minimum wage, decent healthcare and so on. The other attractive feature has been that, again unlike the American government, the European Union has not been completely dominated by large business interests. Most EU funding ultimately flows from taxes paid by voters in member states, so their demand for social rights carries weight in the European Commission.

However, the EU's recent behaviour towards Greece seems to contradict both of these features of past EU practice. On the one hand, the austerity measures seem to take no account of the intense and prolonged human suffering they are causing by preventing Greeks from obtaining many of the social rights they are used to having; in effect, taking those away. On the other hand, the loans being given to the Greek government are not intended to develop Greece's infrastructure, invest in Greek enterprises, encourage growth or create jobs. Instead, they will be used to repay debts to European bankers. So the EU is apparently putting the interests of corporate big business above those of ordinary people. That is certainly how it looks on the streets.

How does this express itself in terms of the dynamics of humiliation or forced social displacement? For a start, it is noticeable that coverage of the crisis in the Greek media is pushing together two things. One is the fact that ordinary citizens are not being treated in a decent way, and are having to bear inhuman conditions: meaning loss of jobs, cuts in pensions, reduction of wages, increases in taxes, and so on. The other theme is that the damage and hurt the Greeks are experiencing is being caused by Germans and this fact is offensive to Greece's national honour.

To coin a phrase, this adds insult to injury; more precisely, it adds national insult to personal injury. It brings into play the honour code, which values strength, and is sometimes prepared to consider violence. It is not surprising to see stereotypes being projected in the other direction also, from Brussels and Berlin against the Greeks, and equally unfairly. Again the American parallel is suggestive. The citizens of New Orleans were told by their "betters" in Washington and elsewhere that their bad circumstances were largely due to the workings of an impersonal force, the weather, which no one can control, and that they, the local people, were to blame for the disaster because they should have exercised more foresight and built better defences against possible hurricanes. 
The defence to this charge is that, as is normal, the people of New Orleans left that task to their political leaders, both locally in city and centrally in Washington. And they were let down by both sets of leaders. Compare Athens. The situation can be described in almost the same words.

Superior-sounding outsiders have been telling Greeks that their bad circumstances are largely due to the workings of an impersonal force, the market, which no one can control, and that they only have themselves to blame for the disaster because they should have exercised more foresight and built better defences against possible economic hurricanes. In fact, as is normal, the people of Greece left that task to their political leaders, both the government in Athens and the EU in Brussels. And they were let down by both sets of leaders. As in America, so in Europe: both the local and the central leadership failed to carry through the necessary task because of the short-term costs involved. Hence the unmanageable debts and the bitter austerity packages. Hence the angry demonstrations.

However, there is one thing left out of that analysis: in New Orleans and the state of Louisiana there is a long history of clientelism, corruption and patronage; it has been reported that there are also some elements of this in Greece. Have citizens in either Greece or Louisiana given sufficient support to movements that could have changed this and made them less vulnerable to challenges such as the hurricane and the credit crunch?

However, a more immediate question is how have Greeks responded to these recent humiliations? Contrast once more the case of New Orleans, where a very widespread citizens' response to their situation was a "yielding" response: escape to other cities. This was dictated by opportunity and by necessity. By opportunity because distances were short, language was not a problem, transport was available and relatives were willing. By necessity because so much of the city's housing had been destroyed.

In the case of Greece, escape is not so high on the agenda, although it may become so for many young people if they choose to emigrate. In Athens, unlike New Orleans, people still have a city in which they can demonstrate. Greek citizens who are unable or unwilling to either escape or accept the humiliation being imposed upon them, are turning instead towards challenge responses. Resistance-rejection would mean finding ways to strengthen Greece's capacity to withstand financial and political pressure. That depends upon finding the means to build a stronger economy and put in place a government that has strong public backing. At the moment that seems very difficult 
to achieve, although it must be assumed that many people are working on it.

Meanwhile, a strong current of revenge-rejection seems to be building. For example, insults are being poured on Brussels and Berlin in the media and on the streets. Any Greek politician who has been involved in supporting the austerity packages is also likely to be "slaughtered" at the polls, to use the language of the honour code, whenever the next election is held. Looking further ahead, it would not be surprising to see a degree of increased political instability in Greece, for a while at least, especially while half of Greece's young people are without a job.

At the moment, the Greek state probably has at least two cards in its hand. One is anxiety within the EU that if Greece leaves the Euro it will weaken the credibility and prestige of the currency with bad effects across the EU. The second is that political instability within Greece might have damaging consequences for the stability of South-Eastern Europe as a whole. However, those two cards may not be as strong as they seem. It is not clear that the EU politicians and officials will have the political ability over the next few years to avert those dangers by keeping Greece within the Euro and inside the EU.

We should consider that some quite well-organized interests might quite like to see the disruption that a Greek exit from the Euro and the EU would cause. I am referring to speculators: financial speculators and political speculators. Financial speculators are able to make profits from sudden and extreme movements in currencies, bonds, shares and so on, whether these movements are up or down. The break up of the Euro would be a great money-making opportunity, especially for those who can shift their assets across the world, taking their winnings away from the scene of destruction.

Political speculators live off the passions generated by humiliation, using them as a source of energy. Such speculators might be able to use that political energy to try and weaken institutions and structures they dislike, and then create power bases for themselves. This is not intrinsically either good or bad: after all, one such speculator was Mahatma Gandhi. However, my point here is that this possibility must be factored in.

The next election, whenever it goes ahead, is expected to transform the landscape of political parties: how much is a matter of debate. Obviously this will put many existing understandings and expectations in doubt, especially in the public sector. That makes it a moment both of danger and of opportunity. As power balances change and resources become very scarce there may be talk of "settling old scores" within Greek society and politics. When the poli- 
tics of giving rewards becomes difficult, the politics of inflicting punishments raises its head. However, it is perhaps also an opportunity to pool the society's resources and rebuild the Greek political economy.

I will risk one observation. This is that nothing can be done unless the main actors involved recognise that beside the historical track along which they are travelling stands a huge lever. To use an image from old technology, and old silent films, this lever is like those devices that shift railways lines from one direction to another by moving the points. The question is: which line do the citizens of Greece want to go down as they respond to the intense humiliation they are now experiencing? Do they want to go down the track of repeated cycles of revenge? How many people would wish that future on their grandchildren? Or do they want to go down the track of conciliation-reform, involving the pursuit of structural change and positive engagement with the other, or indeed various others? Such a future seems more promising.

\section{POSSIBLE FURTHER READING}

I would very much appreciate comments on my argument, both theoretical and empirical. My email address is d.smith@lboro.ac.uk and my university website is at http://www.lboro.ac.uk/departments/ss/staff/staff_biog/smith.html

Some specific citations and arguments relating to the themes of humiliation and displacement may be found in the following works by the author:

"Organization and humiliation. Looking beyond Elias", Organization, vol. 8, no 3, 537- 60, 2001.

Globalization. The Hidden Agenda (Polity 2006).

"Social Fluidity and Social Displacement", Sociological Review, vol 58, no 4, November 2010, 680-8.

"Dimensions of World Making: Thoughts from the Caspian Sea" in A. Dennis - D. Kalekin-Fishman (eds), The Shape of Sociology for the 21st Century, Sage (forthcoming).

"Inside stories: Oscar Wilde, Jean Améry, Nelson Mandela and Aung San Suu Kyi", in Nicolas Demertzis (ed.), Emotions in Politics, London, Palgrave-Macmillan (forthcoming). 


\section{APPENDIX A}

\section{FIGURE 1}

Key Dispositions tested by Humiliation

\begin{tabular}{|r|l|}
\hline $\begin{array}{r}\text { Disposition of the } \\
\text { humiliated person } \\
\text { or group }\end{array}$ & $\begin{array}{l}\text { Towards } \\
\text { the "inner" }\end{array}$ \\
\hline $\begin{array}{r}\text { Towards the } \\
\text { "outer" }\end{array}$ & $\begin{array}{l}\text { Towards } \\
\text { the "other" }\end{array}$ \\
\hline
\end{tabular}

FIGURE 2

Four Possible Responses to Humiliation

\begin{tabular}{|l|l|l|}
\hline \multirow{2}{*}{$\begin{array}{l}\text { Yielding } \\
\text { Responses }\end{array}$} & ESCAPE & $\begin{array}{l}\text { tries to remove the potential } \\
\text { object of humiliation }\end{array}$ \\
\cline { 2 - 3 } & ACCEPTANCE & $\begin{array}{l}\text { tries to remove the objection } \\
\text { to humiliation }\end{array}$ \\
\hline \multirow{2}{*}{$\begin{array}{l}\text { Challenging } \\
\text { Responses }\end{array}$} & REJECTION & $\begin{array}{l}\text { tries to eliminate the } \\
\text { effects of humiliation }\end{array}$ \\
\cline { 2 - 3 } & REFORMILIATION- & $\begin{array}{l}\text { tries to eliminate the } \\
\text { causes of humiliation }\end{array}$ \\
\hline
\end{tabular}


FIGURE 3

Requirements of Success and Costs of Failure

\begin{tabular}{|l|l|l|l|}
\hline \multirow{2}{*}{$\begin{array}{l}\text { Yielding } \\
\text { Responses }\end{array}$} & ESCAPE & $\begin{array}{l}\text { Success requires } \\
\text { control of fear }\end{array}$ & $\begin{array}{l}\text { Failure may lead to } \\
\text { Fear Cycle }\end{array}$ \\
\cline { 2 - 4 } & ACCEPTANCE & $\begin{array}{l}\text { Success requires } \\
\text { trust and reciprocity }\end{array}$ & $\begin{array}{l}\text { Failure may lead to } \\
\text { Victimization Cycle }\end{array}$ \\
\hline \multirow{2}{*}{$\begin{array}{l}\text { Challenging } \\
\text { Responses }\end{array}$} & REJECTION & $\begin{array}{l}\text { Success requires } \\
\text { control of anger }\end{array}$ & $\begin{array}{l}\text { Failure may lead to } \\
\text { Revenge Cycle }\end{array}$ \\
\cline { 2 - 4 } & $\begin{array}{l}\text { CONCILIATION- } \\
\text { REFORM }\end{array}$ & $\begin{array}{l}\text { Success requires con- } \\
\text { trol and reciprocity }\end{array}$ & $\begin{array}{l}\text { Failure may lead to } \\
\text { Distrust Cycle }\end{array}$ \\
\hline
\end{tabular}

FIGURE 4

Honour Code and Human Rights Code

\begin{tabular}{|l|l|}
\hline $\begin{array}{l}\text { The HONOUR CODE recognizes as } \\
\text { "honourable" an actor's }\end{array}$ & $\begin{array}{l}\text { The HUMAN RIGHTS CODE recog- } \\
\text { nizes that all actors have RIGHTS, } \\
\text { including... }\end{array}$ \\
\hline $\begin{array}{l}\text { ST capacity to enter, survive, and achieve } \\
\text { success in the social struggle, even at the } \\
\text { cost of damaging or destroying rivals }\end{array}$ & $\begin{array}{l}\text { (i) the right to enter, and be fairly treated } \\
\text { in, the social competition (eg. for jobs } \\
\text { and income) }\end{array}$ \\
\hline $\begin{array}{l}\text { (ii) capacity to provide or withhold care } \\
\text { and protection for others, or damage or } \\
\text { destroy others at will, and }\end{array}$ & $\begin{array}{l}\text { (ii) rights with respect to the provision } \\
\text { of care and protection }\end{array}$ \\
\hline $\begin{array}{l}\text { (iii) capacity to provide or withhold life- } \\
\text { enhancing benefits }\end{array}$ & $\begin{array}{l}\text { (iii) rights with respect to life-enhancing } \\
\text { benefits }\end{array}$ \\
\hline
\end{tabular}


FIGURE 5

\section{Potential Allies for Conciliation-Reform}

\begin{tabular}{|l|l|l|l|}
\hline & \multicolumn{3}{|l|}{ Disposition towards: } \\
\hline & $\begin{array}{l}\text { Transformation } \\
\text { of The Inner }\end{array}$ & $\begin{array}{l}\text { Transformation } \\
\text { of The Outer }\end{array}$ & $\begin{array}{l}\text { Positive Engagement } \\
\text { with The Other }\end{array}$ \\
\hline & Transformation & Transformation & Positive Engagement \\
\hline Conciliation-Reformers & Strong & Strong & Strong \\
\hline Resistance-Rejecters & Strong & Strong & Weak \\
\hline Accepters & Strong & Weak & Strong \\
\hline Revenge-Resisters & Weak & Weak & Weak \\
\hline Escapees & Weak & Weak & Weak \\
\hline
\end{tabular}

